\title{
Migration of dissolved organic carbon in biochars and biochar-mineral complexes
}

\author{
Yun Lin(1), Paul Munroe ${ }^{(1)}$, Stephen Joseph(1) and Rita Henderson ${ }^{(2)}$
}

\begin{abstract}
${ }^{(1)}$ The University of New South Wales (UNSW), School of Material Science and Engineering, NSW 2052, Australia. E-mail: yun.lin@unsw.edu.au, p.munroe@unsw.edu.au, joey.stephen@gmail.com ${ }^{(2)}$ UNSW, Water Research Centre, School of Civil and Environmental Engineering, NSW 2052, Australia. E-mail: r.henderson@unsw.edu.au
\end{abstract}

\begin{abstract}
The objective of this work was to determine the contribution of dissolved organic carbon (DOC) from a biochar mineral complex (BMC), so as to better understand the interactions between DOC, biochar, clay, and minerals during thermal treatment, and the effects of BMC on amended soils. The BMC was prepared by heating a mixture of a $\mathrm{H}_{3} \mathrm{PO}_{4}$-treated saligna biochar from Acacia saligna, clays, other minerals, and chicken manure. The BMC was applied to a sandy loam soil in Western Australia, where wheat was grown. Liquid chromatography-organic carbon detection (LC-OCD) tests were carried out on water extracts from the untreated biochar, the BMC, the BMC-amended soil, and on a control soil to measure the DOC concentration. LC-OCD tests provide a fingerprint of the DOC, which allows the fractions of DOC to be determined. Thermal processing enhanced the reaction of the A. saligna biochar with manure, clays and minerals, and affected the distribution of the DOC fractions. Notably, the process leads to immobilization of hydrophobic DOC and to an increase in the concentration of low-molecular-weight neutrals in the BMC. The application of the BMC to soil increases the DOC in the amended soil, especially the biopolymer fraction.
\end{abstract}

Index terms: LC-OCD, carbon fractionation, humic substances, thermal treatment, soil carbon dynamics, water-extractable organic carbon.

\section{Migração de carbono orgânico dissolvido em "biochar" e complexos minerais de "biochar"}

Resumo - O objetivo deste trabalho foi determinar a contribuição do carbono orgânico dissolvido (COD), de um complexo mineral de "biochar" (BMC), para uma melhor compreensão das interações entre COD, "biochar", argila e minerais durante o tratamento térmico, e dos efeitos do BMC sobre solos tratados. O BMC foi preparado por meio do aquecimento de uma mistura de "biochar" produzido a partir de Acacia saligna, tratado $\mathrm{com}_{3} \mathrm{PO}_{4}$, argilas, outros minerais e esterco de galinha. O BMC foi aplicado a um Argissolo Vermelho-Amarelo distrófico arênico na Austrália Ocidental, onde cultivou-se trigo. Testes de cromatografia líquida com detecção de carbono orgânico (LC-OCD) foram realizados em extratos aquosos do biocarvão não tratado, do BMC, do solo tratado com BMC, e de um solo testemunha, para medir a concentração de COD. Os testes de LC-OCD fornecem uma identificação do COD, o que permite que as frações de COD sejam determinadas. O processamento térmico aumentou a reação do "biochar" produzido a partir de A. saligna com o esterco, argilas e minerais, e afetou a distribuição das frações de COD. Notavelmente, o processo leva à imobilização do COD hidrofóbico e a um aumento na concentração de substâncias neutras com baixo peso molecular no BMC. A aplicação do BMC ao solo aumenta o COD no solo tratado, principalmente a fração de biopolímero.

Termos para indexação: LC-OCD, fracionamento do carbono, substâncias húmicas, tratamento térmico, dinâmica de carbono no solo, carbono orgânico extraível por água.

\section{Introduction}

Dissolved organic carbon(DOC) or water-extractable organic carbon (Weoc) represents a small proportion of soil organic matter, but plays many roles in the soil ecosystem, largely due to its mobility and reactivity, affecting soil biological activity, transporting metal contaminants and mineral weathering (Chantigny, 2003).
The amount of DOC has been correlated with the soil microbial production of $\mathrm{CO}_{2}$ and dehydrogenase activity (Rees \& Parker, 2005). The biodegradability of DOC also depends on both land use and land management practices (Scaglia \& Adani, 2009). Based on studies of environmental controls on dissolved organic matter concentrations and fluxes in soils, Kalbitz et al. (2000) indicated that litter and humus are the most important DOC sources in soils. Under field

Pesq. agropec. bras., Brasília, v.47, n.5, p.677-686, maio 2012 
conditions, hydrologic variations in soil horizons with high carbon contents are possibly more important than biotic controls.

Moreover, DOC can also be trapped within mineral soils by adsorption, which can result in its immobilization and stabilization (Schneider et al., 2010). This may be strongly associated with Fe and Al oxides and oxyhydroxides (Kothawala et al., 2009). The adsorption-desorption equilibrium between the dissolved phase and the solid phase of soil organic matter depends on the colloidal properties of soils, such as their ionic strength, valence of the involved cation, and $\mathrm{pH}$ value (Münch et al., 2002).

As a soil-amendment carbonaceous material, biochar, or black carbon, formed by natural fires or pyrolysis of biomass under anoxic conditions, contribute $1-10 \%$ of total organic matter in soils and sediments (Gustafson \& Gschwend, 1997). The humic acids, obtained from chemical oxidation of eucalyptus charcoal (charred at 300, $350,400,450,500$, and $550^{\circ} \mathrm{C}$ ) and from volcanic soils, have similar characteristics of biochar (Trompowsky et al., 2005).

When biochar is applied into soils its DOC contents directly increase the soil organic matter content and soil-DOC pool, subsequently affecting the adsorption-desorption equilibrium between the dissolved phase and the solid phase of the soil (Smernick, 2009). It has also been reported that the microbial communities are changed in biochar-amended soils (Steinbeiss et al., 2009; Jin, 2010). Additions of plant litter (sugarcane leaves) were more rapidly incorporated into a soil aggregate and organic-mineral fractions when black carbon was present (Liang et al., 2010), which indicates a significant impact of biochar on soil carbon dynamics.

It has recently been demonstrated that biochar mineral complexes (BMC's) - biochars mixed with manure, clays, and other minerals at low temperatures - would result in the formation of redox active phases which would have variable charge structures along with a range of oxygenated labile organic $\mathrm{C}$ and $\mathrm{N}$ compounds, some of which intercalated into the mineral phases (Joseph et al., 2010). It has been suggested that the heterogeneous phase structures in BMCs containing both labile and recalcitrant $\mathrm{C}$ would have surfaces which may promote growth of beneficial micro-organisms and increase the rate of nutrient cycling (Gilbert \& Banfield, 2005). However, little is known about the DOC present in these materials and how the distribution of the DOC is altered following thermal process and interaction with soil.

Liquid chromatography-organic carbon detection (LC-OCD) is an automated size-exclusion form of chromatography, which can be used to measure low concentrations of organic carbon in water with high sensitivity. The organic substances detected can also be fractioned based on their molecular weight (Huber et al., 2011).

The objective of this work was to determine the contribution of DOC from the BMC, so as to better understand the interactions among DOC, biochar, clay, and minerals during heating, and the effects of BMC on amended soils.

\section{Materials and Methods}

The biochar used was produced from Acacia saligna wood chips by pyrolysis, at approximately $400^{\circ} \mathrm{C}$ for four hours. The biochar was then chemically treated with $10 \%$ phosphoric acid at $90^{\circ} \mathrm{C}$ for 1 hour. To produce BMC, the treated saligna biochar, without separation from solution after reaction, was mixed with clay from a local brickworks (high in calcium sands, apatite and illite), minerals (a high loading of manganese dioxide and waste illemnite), and local chicken litter (with sawdust) from Geraldton, Western Australia. Water was added to the mixture to reach a moisture content of about $30 \%$. This mixture was stirred at $80^{\circ} \mathrm{C}$ for 2 hours and, then, placed into a batch reactor. The material was brought up to $\sim 220^{\circ} \mathrm{C}$ in approximately 1 hour and, then, held at this temperature for 3 hours. Then, butenolide was applied to assist in germination (Light et al., 2009).

The BMC was applied to a sandy loam soil at a rate up to $300 \mathrm{~kg} \mathrm{ha}^{-1}$, where wheat was grown. The field trial was carried out in April 2009 at Moonyoonooka, Western Australia, an experimental site of the Western Australia Department of Agriculture and Food. Four replicates were applied in $150 \mathrm{~mm}$ ground tubes. 
The plants were irrigated with overhead sprays. After harvest, three soil samples were randomly taken from the top $10 \mathrm{~cm}$ of each replicate and pooled to be representative of the soil.

To analyze the surface chemical composition and carbon bonding state, the saligna biochar, the $\mathrm{H}_{3} \mathrm{PO}_{4}$-treated saligna biochar and the $\mathrm{BMC}$ were investigated by $\mathrm{X}$-ray photoelectron spectrometry (XPS) VG Escalab-220i-XL (VG Scientific, West Sussex, UK) with a monochromatic Al K $\alpha$ $\mathrm{X}$-ray source $(\mathrm{h} v=1486.6 \mathrm{eV})$ induced by $10 \mathrm{kV}$, $15 \mathrm{~mA} \mathrm{Al} \mathrm{K \alpha}$ radiation with a spot size $\sim 1 \mathrm{~mm}$ in diameter. The pass energy for survey scans was $100 \mathrm{eV}$ with a scan step of $1 \mathrm{eV}$, and for region scans, $20 \mathrm{eV}$ with a scan step of $0.1 \mathrm{eV}$. The peak fitting program, Eclipse 2.0, was used to deconvolute the $\mathrm{C} 1 \mathrm{~s}$ peak. The $\mathrm{C} 1 \mathrm{~s}$ peak fitting results from the saligna biochar, $\mathrm{H}_{3} \mathrm{PO}_{4}$-treated saligna biochar and BMC are listed in Table 1.

For direct observation of the BMC surface, BMC particles were coated with $\mathrm{Cr}$ to induce conductivity and examined using a Hitachi 3400N scanning electron microscope (SEM) (Hitachi Ltd., Mito Works, Hitachinaka City, Ibaraki Prefecture, Japan) to which energy-dispersive x-ray spectroscopy facilities (EDS) were attached. To produce cross-sections of the biochar and BMC, samples were embedded in epoxy resin and mirror-polished. The polished samples were coated with $\mathrm{Cr}$ either for SEM observation and analysis, or via a focused ion beam (FIB) microscope, used to prepare an electron transparent section for the examination by the transmission electron microscope (TEM) Philips CM200 field emission gun (Philips/FEI, Eindhoven, The Netherlands).

All treatments underwent a water extraction procedure to prepare specimens for LC-OCD. Ten grams of the sample material were added to $100 \mathrm{~mL}$

Table 1. X-ray photoelectron spectrometry C 1s peak bonding state and its relative percentage in the saligna biochar, $\mathrm{H}_{3} \mathrm{PO}_{4}$-treated biochar and biochar mineral complex (BMC) surfaces.

\begin{tabular}{|c|c|c|c|c|}
\hline \multirow{2}{*}{$\begin{array}{l}\text { Centre } \\
(\mathrm{eV})\end{array}$} & \multirow[t]{2}{*}{ Structure } & Saligna biochar & Treated biochar & BMC \\
\hline & & \multicolumn{3}{|c|}{ 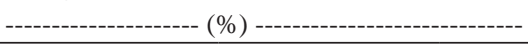 } \\
\hline $289.2 \pm 0.1$ & Carboxylic & 0.0 & 0.0 & 3.1 \\
\hline $288.0 \pm 0.2$ & $\mathrm{C}=\mathrm{O}$ & 3.3 & 2.0 & 6.8 \\
\hline $286.5 \pm 0.1$ & $\mathrm{C}-\mathrm{O}$ & 8.0 & 10.9 & 19.5 \\
\hline $285.0 \pm 0.0$ & $\mathrm{C}-\mathrm{C} / \mathrm{C}-\mathrm{H}$ & 88.7 & 87.7 & 70.6 \\
\hline
\end{tabular}

distilled water at $50^{\circ} \mathrm{C}$ for 24 hours and regularly stirred, and then centrifuged and filtered to separate the solid and liquid phases. The supernatants were passed through $0.45 \mu \mathrm{m}$ filter and analyzed (two replicates) by a LC-OCD Model 8 (DOC-Labor, Karlsruhe, Germany), which is an automated size-exclusion chromatography coupled to three detectors, organic carbon, organic nitrogen and UV-absorbance. Details of the measurement procedure have been described in full by Huber et al. (2011). In the present study, a Toyopearl TSK HW50S column (TOSOH Bioscience GmbH, Stuttgart, Germany) was utilized using phosphate buffer mobile phase of $\mathrm{pH} 6.4\left(2.6 \mathrm{~g} \mathrm{~L}^{-1} \mathrm{KH}_{2} \mathrm{PO}_{4}\right.$ and $1.5 \mathrm{~m} \mathrm{~L}^{-1} \mathrm{Na}_{2} \mathrm{HPO}_{4}$ ) at a flow rate of $1.1 \mathrm{~mL}$ per min. Injection volumes were $1,000 \mu \mathrm{L}$. The chromatographic column is a weak cation exchange column on polymethacrylate basis. The chromatography subdivides DOC in a water solution into six sub-fractions, which are assigned to specific classes of compounds: biopolymers, humic substances, building blocks, low-molecular-weight acids, low-molecular-weight neutrals, and hydrophobic organic carbon (Huber et al., 2011). The fraction of biopolymer is a hydrophilic fraction with high molecular weight, indicating the presence of polysaccharides with some contribution from nitrogen-containing materials, such as proteins or aminosugars, which represent non-humic matter. The fraction of building blocks reflects the breakdown products from humic substances. The fraction of low-molecular-weight (LMW) acids mainly represents LMW monoprotic organic acids. In the fraction of LMW neutrals, LMW alcohols, aldehydes, ketones, sugars, and LMW amino acids are the principal components. The fraction of hydrophobic organic carbon represents the fraction of DOC remaining in the column, implying strong hydrophobic interaction with the column material. The DOC data variation is around $5-10 \%$.

\section{Results and Discussion}

The XPS analysis showed that carboxylic carbon was not detectable on the surfaces of the untreated and $\mathrm{H}_{3} \mathrm{PO}_{4}$-treated saligna 
biochar, and the carbon was mainly (88-89\%) in a $\mathrm{C}-\mathrm{C} / \mathrm{C}-\mathrm{H}$ bonding state (Table 1 ). The $\mathrm{H}_{3} \mathrm{PO}_{4}$-treated biochar showed a slight increase in the concentration of $\mathrm{C}-\mathrm{O}$ bonds. After heating with minerals and manure, the proportion of carbon bonding with oxygen on the BMC surface increased. Carboxylic carbon was detected and was calculated to be $\sim 3 \%$ (relative percentage). The increase in the $\mathrm{O}$-containing carbon compounds mainly resulted from the organic matter in the chicken manure, which has been adsorbed by the $\mathrm{H}_{3} \mathrm{PO}_{4}$-treated saligna biochar and clays in the BMC. The other contribution may come from surface oxidation of the biochar during thermal process due to redox reactions (Joseph et al., 2010).

Clay and mineral particles (visible as bright regions) adhered to the biochar surface, as shown in a typical secondary electron SEM image captured from a single BMC particle (Figure $1 \mathrm{~A}$ ). However, the biochar surface was not completely covered by these phases. The cross-sectional SEM image, depicted in Figure $1 \mathrm{~B}$, showed a typical woody structure, indicating that most of pores inside the biochar were free of mineral phases. The mineral attachment occurred preferentially around the biochar external surface within the open porous structure. This possibly resulted from physical protection of these mineral particles from washing away and chemical interaction of the biochar and mineral phases.

During the heating process, the $\mathrm{H}_{3} \mathrm{PO}_{4}$-treated saligna biochar combined with the added clay and minerals, as shown in the cross-sectional SEM-EDS elemental maps of BMC particles (Figure 2). Nutrient elements, such as $\mathrm{P}$ and $\mathrm{K}$, were present in the BMC. Some $\mathrm{Ca}$, possibly $\mathrm{CaO}$ or CaCO3, was noted to have migrated into the charcoal pores. Other elements, such as $\mathrm{Fe}, \mathrm{Ti}, \mathrm{Mg}$ and $\mathrm{Mn}$, were noted within the mineral phases of the BMC.

The mineral phases were noted to be directly adjacent to biochar and were composed of fine mineral grains, less than $200 \mathrm{~nm}$ in diameter, as shown by cross-sectional transmission electron microscopy of the interface between the biochar and mineral phases (Figure 3). There were three locally adjacent regions selected (circled in Figure 3) where EDS punctual analysis was performed, which was inside the mineral phase (1), on the mineral phase close to biochar surface (2), and on the biochar phase next to a mineral phase (3). EDS spectrum 1 indicated the presence of a clay particle (possible silicate, as indicated by significant $\mathrm{Si}$ and $\mathrm{O}$ peaks), some $\mathrm{Mn} / \mathrm{Fe}$ (possible oxides) and relatively high $\mathrm{Ca} / \mathrm{P}\left(\mathrm{CaPO}_{4}\right)$ co-exist inside the mineral phase. In spectrum 2, a significant $\mathrm{P}$ content and high contents of $\mathrm{Ca}, \mathrm{K}$, $\mathrm{Mn}$ and Fe were noted. Sulphur was also detected.
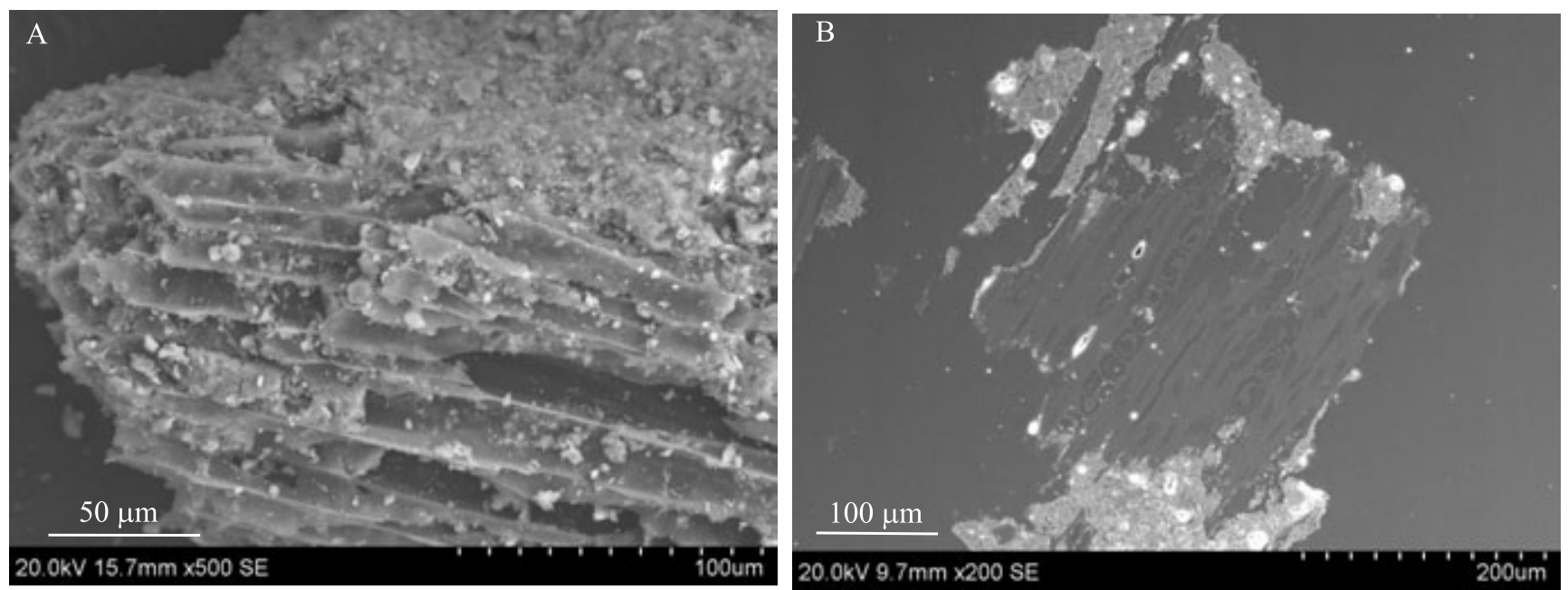

Figure 1. Scanning electron microscope (SEM) images captured from biochar mineral complex (BMC) particle surface (A); cross-section of BMC particle (B). 

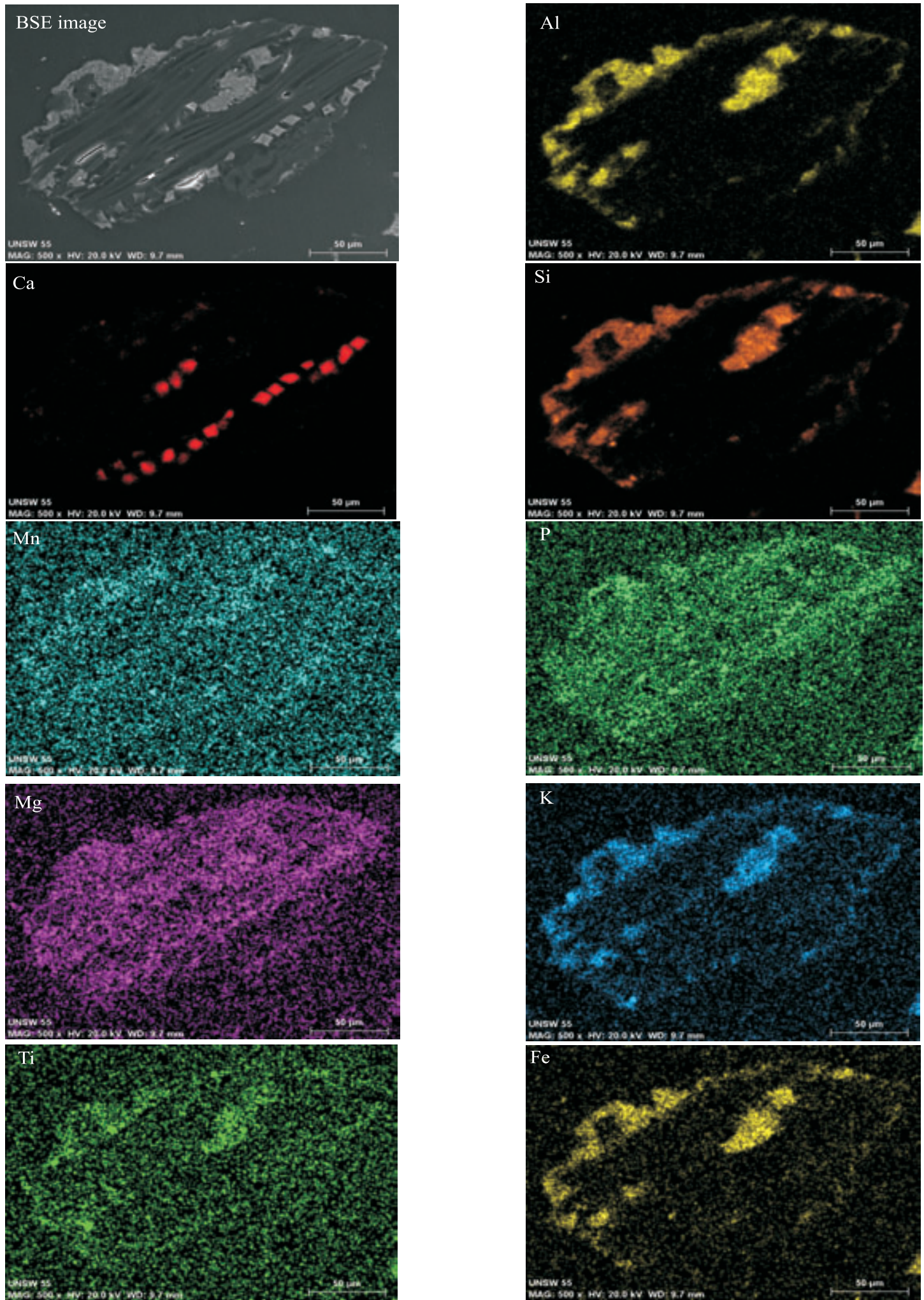

Figure 2. Elemental maps from a cross-section of a biochar mineral complex (BMC) particle (scale bar: $50 \mu \mathrm{m}$ ) using scanning electron microscope with energy-dispersive X-ray spectroscopy attached facilities (SEM-EDS). First column from top to bottom: backscattered SEM image, Ca, Mn, Mg, and Ti. Second column from top to bottom: Al, Si, P, K, and Fe. 
This implied that these elements preferentially segregated to the biochar during heating, and deposited or adsorbed on to the biochar surface. At the biochar side of this interface, spectrum 3 showed the presence of $\mathrm{C}$, but elements such as $\mathrm{Ca}, \mathrm{K}, \mathrm{Fe}, \mathrm{Mn}, \mathrm{P}, \mathrm{Na}$ and $\mathrm{S}$ were also noted, which probably came from soluble sodium salts (such as sulphates) in the feedstock materials of the BMC and become absorbed by the biochar during heating. Possible interactions included negatively charged surfaces of biochars which can bind to positively charged surfaces of variable-charged oxides by Colombic forces. H-bonding, cation bridging, and ligand exchange reactions may also occur (Joseph et al., 2010).

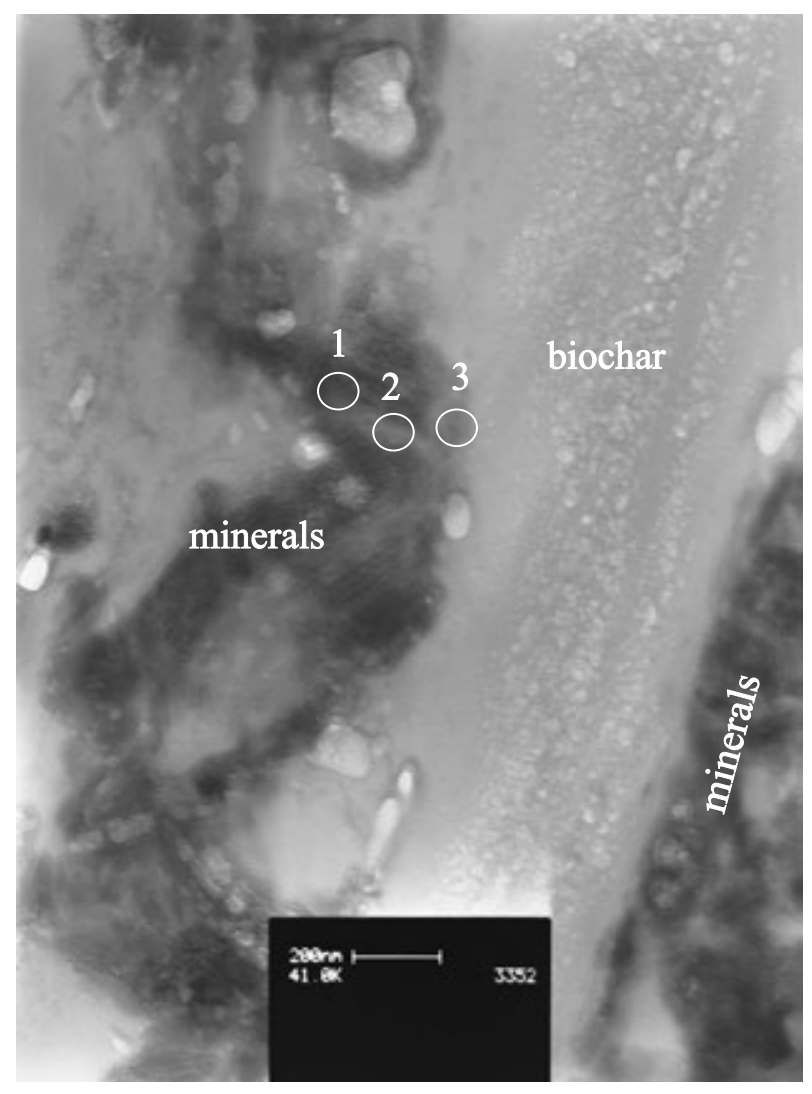

LC-OCD chromatograph and quantitative analysis data from the saligna biochar and BMC are presented in Figure 4 and Table 2, respectively. Although the BMC was a complex of the saligna biochar and clay minerals, the concentration of DOC was similar to that in the saligna biochar itself (205 $\mathrm{mg} \mathrm{L}^{-1}$ and $217 \mathrm{mg} \mathrm{L}^{-1}$, respectively). The DOC in the BMC arises not only from the saligna biochar, but also from the chicken manure (Tan et al., 1975), the butenolide added and the LMW neutrals generated and released from the saligna biochar due to the $\mathrm{H}_{3} \mathrm{PO}_{4}$ treatment (Jagtoyen \& Derbyshire, 1993; Lin et al., 2012). This was also consistent with the appearance of more LMW neutrals and an increase of biopolymer content in the BMC DOC.

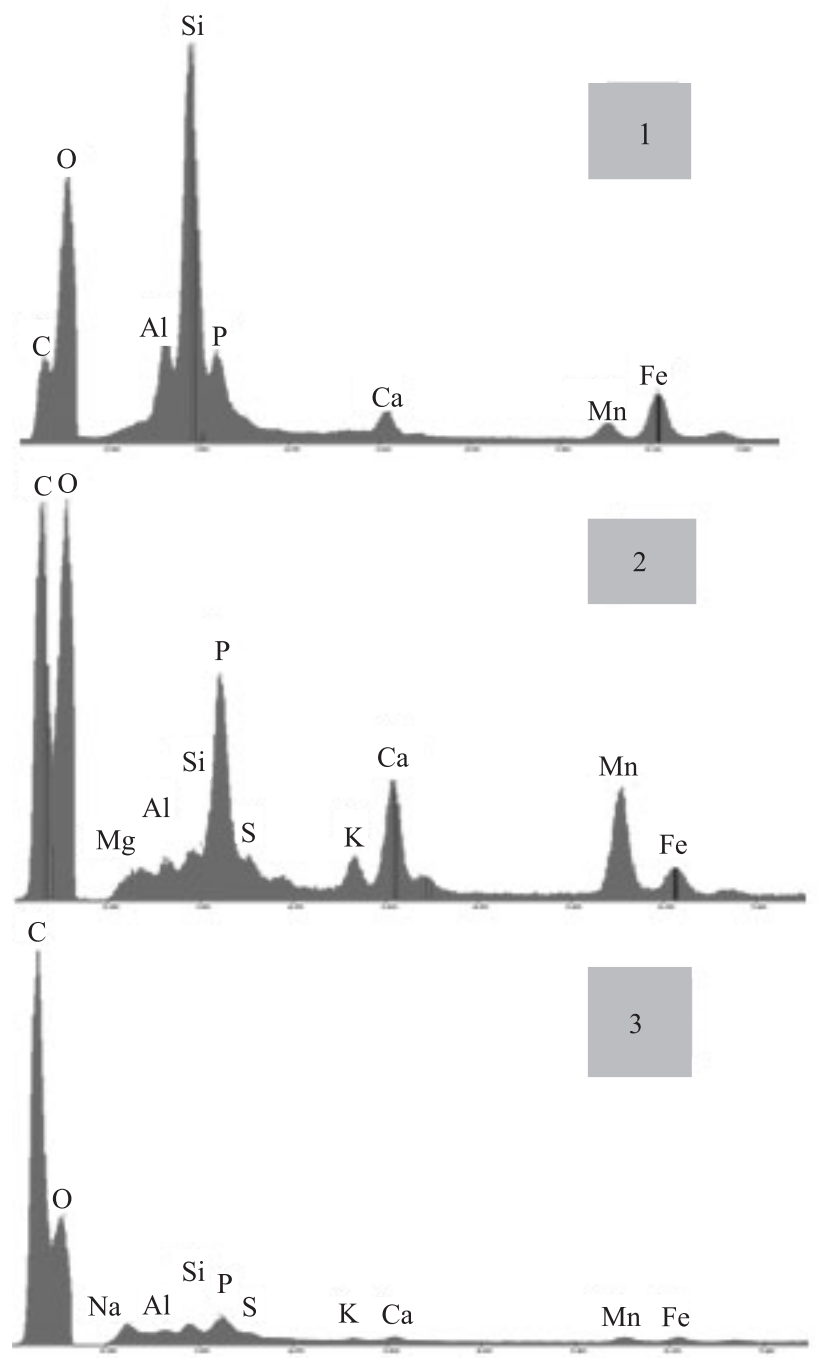

Figure 3. Cross-sectional bright field transmission electron microscope(TEM) image and energy-dispersive X-ray spectroscopy facilities (EDS) spectra from the circled regions across the interface between biochar and adjacent mineral phases. 
Further, it was noted that the hydrophobic DOC fraction decreased to an undetectable level in the BMC, indicating hydrophobic DOC has
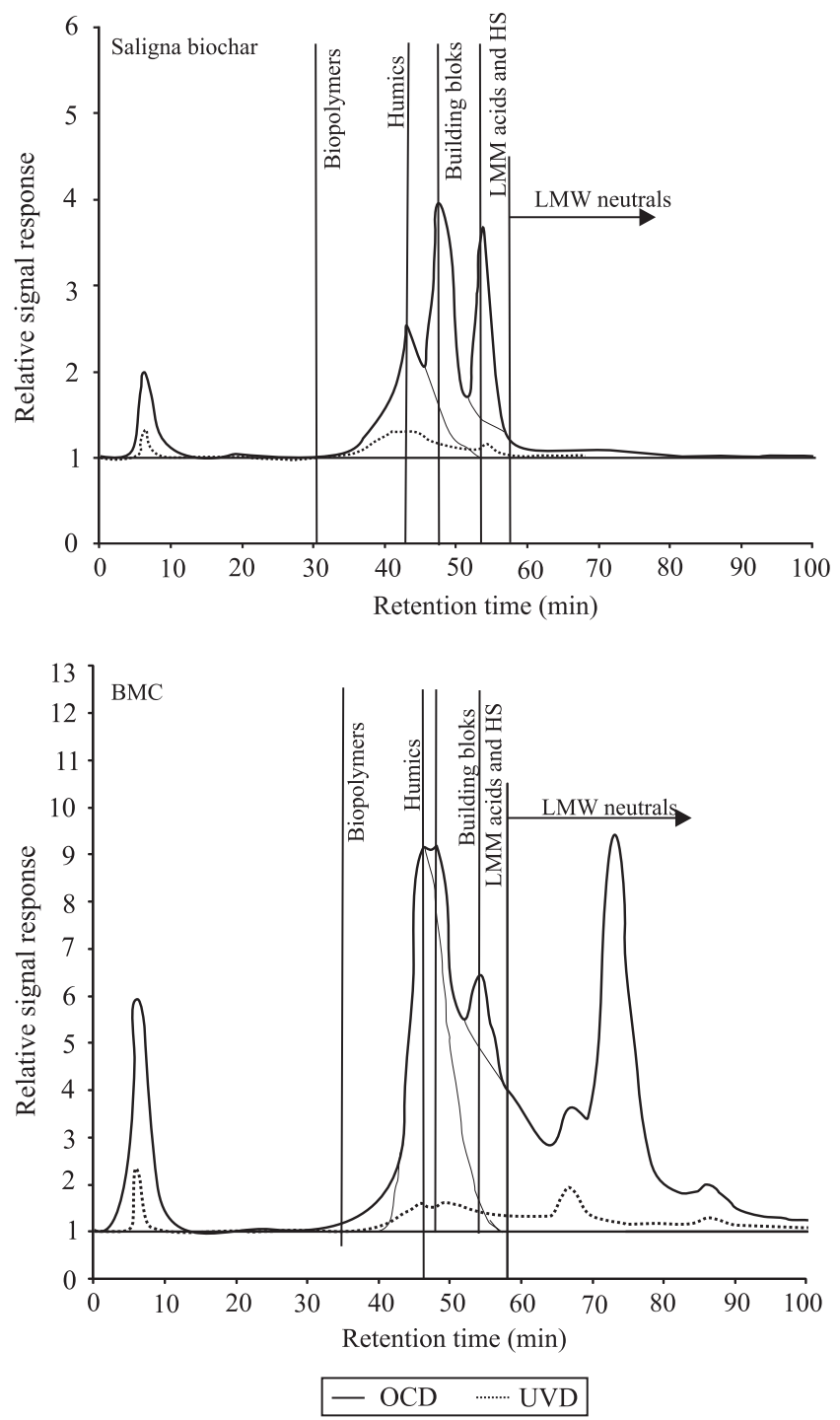

Figure 4. Liquid chromatography-organic carbon detection (LC-OCD) chromatographs from water extracts of the saligna biochar (dilution factor : 100) and biochar mineral complex (BMC) (dilution factor : 20). been fully immobilized in the BMC because of its strong affinity towards clays (Specht et al., 2000) (Table 2). Meanwhile, the concentration of decomposed humics ("building blocks") and LMW acids decreased, likely due to reactions with the minerals added to form precipitates or complexes (Münch et al., 2002). It is interesting to note that, with respect to the humic portion of BMC, the DOC concentration was approximately similar to that of the untreated biochar DOC. However, the aromaticity (as determined using $\mathrm{DOC} / \mathrm{UV}_{254}$ ) and $\mathrm{MW}$ were significantly lower in BMC DOC than that of the biochar DOC, indicating a different source of humics. This is probably related to the different affinity of the humics (from different sources) towards clay minerals. The humics in the saligna biochar may be preferentially/competitively adsorbed by clay because of its higher aromaticity and molecular weight (Balcke et al., 2002). The other possibility is the precipitation and decomposition of the high-molecular-weight humic substances in the saligna biochar due to the $\mathrm{H}_{3} \mathrm{PO}_{4}$ treatment greatly decreasing $\mathrm{pH}$ value (Münch et al., 2002).

The DOC contained in the feedstock of BMC were re-distributed between clay minerals and biochar, during the $\mathrm{H}_{3} \mathrm{PO}_{4}$ treatment and subsequent heating process, due to a $\mathrm{pH}$ decrease and various fractions with different affinity toward either clay or biochar and reactions with minerals. The humic substances with high aromaticity were preferentially adsorbed by kaolin clay (Balcke et al., 2002). The LMW neutrals could replace the interlayer water in smectites (Lagaly, 1984). The decomposed humics ("building blocks") and LMW acids could form complexes with metal ions (Violante \& Gianfreda, 2000) or precipitates (Münch et al., 2002).

Table 2. Concentration of dissolved organic carbon (DOC) and DOC fractions, in the saligna biochar and biochar mineral complex (BMC).

\begin{tabular}{|c|c|c|c|c|c|c|c|c|c|c|c|c|}
\hline \multirow[t]{3}{*}{ Treatment } & \multirow{3}{*}{$\begin{array}{c}\text { DOC } \\
(\mathrm{ppb}-\mathrm{C})^{(1)}\end{array}$} & \multicolumn{2}{|c|}{ Hydrophobic DOC } & \multicolumn{9}{|c|}{ Hydrophilic DOC } \\
\hline & & \multirow[b]{2}{*}{ (ppb-C) } & \multirow[b]{2}{*}{ (\%) } & \multicolumn{2}{|c|}{ Biopolymer } & \multicolumn{4}{|c|}{ Humics } & \multirow[t]{2}{*}{ Building blocks } & \multirow{2}{*}{ LMW-neutrals } & \multirow[t]{2}{*}{ LMW-acids } \\
\hline & & & & (ppb-C) & $\mathrm{N} / \mathrm{C}^{(2)}$ & (ppb-C) & $\mathrm{N} / \mathrm{C}$ & Aromaticity & $\mathrm{MW}^{(3)}$ & & & \\
\hline Saligna biochar & 217,402 & 53,354 & 24.5 & 1,109 & $\mathrm{nq}^{(4)}$ & 62,932 & nq & 8.29 & 782 & 61,842 & 11,195 & 26,970 \\
\hline BMC & 204,964 & $\mathrm{nq}$ & $\mathrm{nq}$ & 12,875 & 0.02 & 57,632 & 0.04 & 2.19 & 286 & 31,602 & 97,523 & 5,332 \\
\hline
\end{tabular}

${ }^{(1)} \mathrm{ppb}-\mathrm{C}$ per $\mathrm{mL}$ water extract (soil:water $\left.=10 \mathrm{~g}: 100 \mathrm{~mL}\right) .{ }^{(2)}$ Nitrogen to carbon ratio. ${ }^{(3)}$ Molecular weight. ${ }^{(4)} \mathrm{Nonquantifiable}(<1 \mathrm{ppb}$ calculated). LMW, low molecular weight. 
For the BMC-amended soil and control soil, the LC-OCD chromatographs showed similar peaks (Figure 5). However, quantitative analysis of the chromatographs indicated different proportions of the various fractions, as listed in Table 3. Addition of the BMC to the sandy loam soil increased the total DOC and the concentration of biopolymer, humics, building blocks and LMW neutrals, which, at least, partly contributed to the proportions
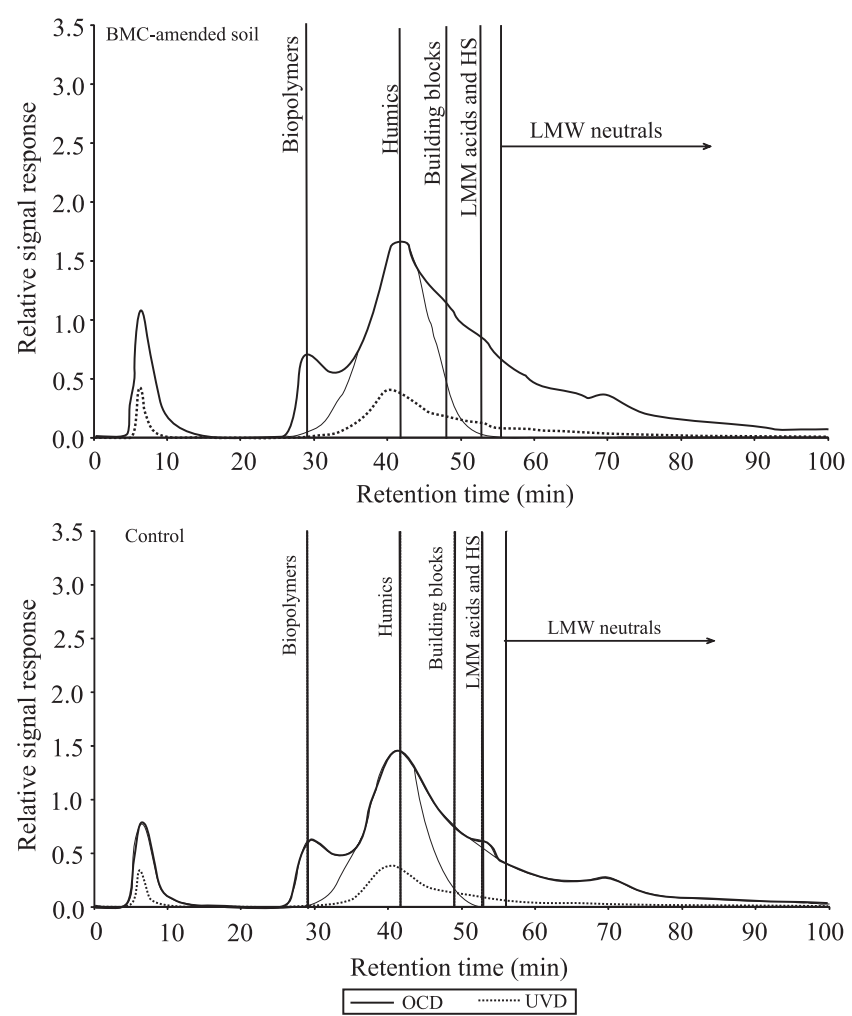

Figure 5. Liquid chromatography-organic carbon detection (LC-OCD) chromatographs from the water extract of biochar mineral complex (BMC)-amended soil and control soil (dilution factor: 10). contained in the BMC. The increase of biopolymer may also indicate enhanced bioactivity in soils. The change of biopolymer N/C ratio, from 0.14 to 0.06 , implied that the microbial communities have changed in the BMC-amended soil. In contrast, it was noted that the concentration of hydrophobic DOC decreased, which could be associated with its adsorption onto the clays in the BMC. Meanwhile, the humic fraction from both soils has the same aromaticity and similar molecular weight, implying the humics from the original soil were relatively stable and were the dominant source of this fraction. The humics in the BMC DOC may not be stable enough in soil because of their lower aromaticity. They may then be oxidized and present in the decomposed humics ("building blocks") fraction. As noticed in Table 3, the decomposed humics also showed a detectable increase.

The BMC DOC directly increased the DOC content in the BMC-amended soil. However, the soil DOC was dominant due to the low application rate of BMC - $300 \mathrm{~kg} \mathrm{ha}^{-1}$. The most apparent change in DOC proportions of the BMC-amended soil was the decrease in hydrophobic DOC portion and the increase in the biopolymer portion. With the BMC addition, clays were added to the field trial sandy soil, causing the adsorption of hydrophobic soil DOC onto the clays in BMC, because of the strong affinity of this kind of DOC towards clays (Specht et al., 2000). Meanwhile, the LMW neutrals in BMC DOC may contribute to soil microbial activity, and resulted in a biopolymer portion increase. The N/C ratio change in detected biopolymers also indicated the shift of microbial communities, which was consistent to the finding by Jin (2010).

Table 3. Concentration of dissolved organic carbon (DOC) and DOC fractions in the biochar mineral complex (BMC)-amended soil, and in the control soil.

\begin{tabular}{|c|c|c|c|c|c|c|c|c|c|c|c|c|}
\hline \multirow[t]{3}{*}{ Treatment } & \multirow{3}{*}{$\begin{array}{c}\text { DOC } \\
(\mathrm{ppb}-\mathrm{C})^{(1)}\end{array}$} & \multicolumn{2}{|c|}{ Hydrophobic DOC } & \multicolumn{9}{|c|}{ Hydrophilic DOC } \\
\hline & & \multirow[b]{2}{*}{ (ppb-C) } & \multirow[b]{2}{*}{$(\%)$} & \multicolumn{2}{|c|}{ Biopolymer } & \multicolumn{4}{|c|}{ Humics } & \multirow[t]{2}{*}{ Building blocks } & \multirow{2}{*}{ LMW-neutrals } & \multirow{2}{*}{ LMW-acids } \\
\hline & & & & (ppb-C) & $\mathrm{N} / \mathrm{C}^{(2)}$ & (ppb-C) & $\mathrm{N} / \mathrm{C}$ & Aromaticity & $\mathrm{MW}^{(3)}$ & & & \\
\hline Control & 17,146 & 1,298 & 7.4 & 1,382 & 0.14 & 8,020 & 0.09 & 5.71 & 718 & 2,477 & 3,954 & 15 \\
\hline BMC-amended & 23,493 & 1,103 & 4.7 & 2,564 & 0.06 & 10,502 & 0.08 & 5.71 & 714 & 3,650 & 5,674 & $\mathrm{nq}^{(4)}$ \\
\hline
\end{tabular}

${ }^{(1)}$ ppb-C per mL water extract (soil:water $\left.=10 \mathrm{~g}: 100 \mathrm{~mL}\right) .{ }^{(2)}$ Nitrogen to carbon ratio. ${ }^{(3)}$ Molecular weight. ${ }^{(4)}$ Nonquantifiable $(<1$ ppb calculated). LMW, low molecular weight. 


\section{Conclusions}

1. $\mathrm{H}_{3} \mathrm{PO}_{4}$ treatment and thermal processing promote interactions of dissolved organic carbon (DOC) and mineral phases in a biochar mineral complex (BMC), which results in fine mineral grain attachment to the surface or into the pores of the biochar.

2. Hydrophobic DOC compounds in BMC are immobilized due to their affinity towards to clays.

3. Application of the BMC into a sandy loam soil increases the soil DOC content, especially biopolymer compounds, in part due to its impact on soil microbial community.

\section{Acknowledgements}

To Anthroterra Pty. Ltd., Australia, for financial support; and to Dr. Paul Blackwell, for the field trial.

\section{References}

BALCKE, G.U.; KULIKOVA, N.A.; HESSE, S.; KOPINKE, F.-D.; PERMINOVA, I.V.; FRIMMEL, F.H. Adsorption of humic substances onto kaolin clay related to their structural features. Soil Science Society of America Journal, v.66, p.1805-1812, 2002.

CHANTIGNY, M.H. Dissolved and water-extractable organic matter in soils: a review on the influence of land use and management practices. Geoderma, v.113, p.357-380, 2003.

GILBERT, B.; BANFIELD, J.F. Molecular-scale processes involving nanoparticulate minerals in biogeochemical systems. Reviews in Mineralogy and Geochemistry, v.59, 109-155, 2005.

GUSTAFSON, O.; GSCHWEND, P.M. Soot as a strong partition medium for polycyclic aromatic hydrocarbons. In: EGANHOUSE, R.P. (Ed.). Molecular markers in environmental geochemistry. Washington: American Chemical Society, 1997. p.365-381.

HUBER, S.A.; BALZ, A.; ABERT, M.; PRONK, W. Characterisation of aquatic humic and non-humic matter with size-exclusion chromatography - organic carbon detection organic nitrogen detection (LC-OCD-OND). Water Research, v.45, p.879-885, 2011.

JAGTOYEN, M.; DERBYSHIRE, F. Some considerations of the origins of porosity in carbons from chemically activated wood. Carbon, v.31, p.1185-1192, 1993.

JIN, H. Characterization of microbial life colonizing biochar and biochar-amended soils. 2010. 196p. Thesis (Ph.D.) Cornell University, Ithaca.
JOSEPH, S.D.; CAMPS-ARBESTAIN, M.; LIN, Y.; MUNROE, P.; CHIA, C.H.; HOOK, J.; VAN ZWIETEN, L.; KIMBER, S.; COWIE, A.; SINGH, B.P.; LEHMANN, J.; FOIDL, N.; SMERNIK, R.J.; AMONETTE, J.E. An investigation into the reactions of biochar in soil. Australian Journal of Soil Research, v.48, p.501-515, 2010.

KALBITZ, K.; SOLINGER, S.; PARK, J.-H.; MICHALZIK, B.; MATZNER, E. Controls on the dynamics of dissolved organic matter in soils: a review. Soil Science, v.165, p.277-304, 2000.

KOTHAWALA, D.N.; MOORE, T.R.; HENDERSHOT, W.H. Soil properties controlling the adsorption of dissolved organic carbon to mineral soils. Soil Science Society of American Journal, v.73, p.1831-1842, 2009.

LAGALY, G. Clay-organic interactions. Philosophical Transactions of the Royal Society of London Series A Mathematical, Physical and Engineering Sciences, v.311, p.315-332, 1984.

LIANG, B.; LEHMANN, J.; SOHI, S.P.; THIES, J.E.; O’NEILL, B.; TRUJILLO, L.; GAUNT, J.; SOLOMON, D.; GROSSMAN, J.; NEVES, E.G.; LUIZAO, F.J. Black carbon affects the cycling of non-black carbon in soil. Organic Geochemistry, v.41, p.206-213, 2010.

LIGHT, M.E.; DAWS, M.I.; VAN STADEN, J. Smoke-derived butenolide: towards understanding its biological effects. South African Journal of Botany, v.75, p.1-7, 2009.

LIN, Y.; MUNROE, P.; JOSEPH, S.; HENDERSON, R.; ZIOLKOWSKI, A. Water extractable organic carbon in untreated and chemical treated biochars. Chemosphere, v.87, p.151-157, 2012.

MÜNCH, J.-M.; TOTSCHE, K.U.; KAISER, K. Physicochemical factors controlling the release of dissolved organic carbon from columns of forest subsoils. European Journal of Soil Science, v.53, p.311-320, 2002.

REES, R.M.; PARKER, J.P. Filtration increases the correlation between water extractable organic carbon and soil microbial activity. Soil Biology and Biochemistry, v.37, p.2240-2248, 2005.

SCAGLIA, B.; ADANI, F. Biodegradability of soil water soluble organic carbon extracted from seven different soils. Journal of Environmental Sciences, v.21, p.641-646, 2009.

SCHNEIDER, M.P.W.; SCHEEL, T.; MIKUTTA, R.; HEES, P. van; KAISER, K.; KALBITZ, K. Sorptive stabilization of organic matter by amorphous Al hydroxide. Geochimica et Cosmochimica Acta, v.74, p.1606-1619, 2010.

SMERNICK, R.J. Biochar and sorption of organic compounds. In: LEHMANN, J.; JOSEPH, S. Biochar for environmental management: science and technology. London: Earthscan, 2009. p.289-300.

SPECHT, C.H.; KUMKE, M.U.; FRIMMEL, F.H. Characterization of NOM adsorption to clay minerals by size exclusion chromatography. Water Research, v.34, p.4063-4069, 2000.

STEINBEISS, S.; GLEIXNER, G.; ANTONIETTI, M. Effect of biochar amendment on soil carbon balance and soil microbial 
activity. Soil Biology and Biochemistry, v.41, p.1301-1310, 2009.

TAN, K.H.; MUDGAL, V.G.; LEONARD, R.A. Adsorption of poultry litter extracts by soil and clay. Environmental Science and Technology, v.9, p.132-135, 1975.

TROMPOWSKY P.M.; BENITES, V. de M; MADARI, B.E.; PIMENTA, A.S.; HOCKADAY, W.C.; HATCHER, P.G.
Characterization of humic like substances obtained by chemical oxidation of eucalyptus charcoal. Organic Geochemistry, v.36, p.1480-1489, 2005.

VIOLANTE, A.; GIANFREDA, L. The role of biomolecules in the formation and reactivity towards nutrient and organics of variable charge minerals and organominerals. In: BOLLAG, J.M.; STOTZKY, G. (Ed.). Soil biochemistry. New York: Marcel Dekker, 2000. v.10, p.207-270.

$\overline{\text { Received on January 31, } 2011 \text { and accepted on April 9, } 2012}$ 